\title{
Making and Breaking of Mythos in Kanthapura by Raja Rao
}

\author{
Chesta Yadav \\ Guest faculty \\ Pannalal Girdharlal Dayanand Anglo-Vedic \\ New Delhi, India \\ chestayadav.cy@gmail.com
}

Abstract

Raj Rao is one of the best Indian writer in English. He is one of the foremost writer whose works is placed in Indo-English literature. Kanthapura earned him international acclaim. The novel portrays the period of the India during 19919 to 19913. Kanthapura and its action represent whole India during that era. The novel is perfect combination of myth, legends and folk tales. This paper attempts to show different myths prevailing in our society and how Raja Rao accepted some myth but on the same time how Raj Rao was standing against some myths of society Keywords: Myth, freedom struggle, Cast System, Sthala-Purana

Myths can't be translated as, they did in their ancient soil.

We can only find our own meaning in our time.

Margaret Atwood

According to Alan W. Watta "Myth is to be defined as a complex of stories some no doubt facts, and some fantasy which for various reasons, human being regard as demonstrations of the inner meaning of the universe and of human life". Myths are expressions of the institution of transcendental reality. People from every part of the world 
draw inspiration and identify themselves with these myths. People are using these myths either consciously or unconsciously. In the same way, myths have always been an integral element of literature. One reason why poets and writers have been drawn towards myth is because they are timelessness. They have fundamental significance. Many few morden writers have made use myth in their works like T.S Eliot in Wasteland. In Wasteland Eliot use myth as an objective correlative which serves as a mirror reflecting his emotions and ideas. Raja Rao employs myth to extend our understanding of a particular situation or give symbolic meaning to the theme undertaken by him. As a great artist, he often assimilates the myth into the narrative. The myths drawn from cultural tradition are interwoven in the texture of his novels. They meander through the plot of the novel in such a manner that they become a medium through which certain situations and characters can be explained and Indian readers especially find it easy to understand the story line. The perfect example of usage of myth is in Raja Rao first novel Kanthapura. Raja Rao employs three types of myth in the novel Puranic myth, Localised myth and Rites, and Rituals. Puranic myth pertains to the binary opposing of the good and evil symbolized through the character of Ram and Ravana. The Ram and Ravan myth appears to be center of the Kanthapura. The novel is frictional rending of localised myth such as of Kenchamma. And in order to create the mythic atmosphere in the novel, Raja Rao has resorted to the mythic atmosphere in the novel, Raj Rao has restored to the depiction of rites and rituals of ploughing worship and sacrifice. But not every myth in the society is glorified by the author some myths in the novel are also broken.

Caste Differentiation biggest myth in our society

Originally the division of caste was to sustain the "social structure" of the society. People were divided on the bases of their work which helped in the smooth functioning of the 
society and the feeling of disparity; due to caste division did not exist. But later the feelings of inequality emerged and disturbed the social order of the society. Many mythical books also support this caste distinction in our society. These books lay down the duties of the people belonging to different caste bringing about disparity and the concept of superiority and inferiority. In Shri Shri Visnu Purana there is a verse, To be extremely polite, to serve the master religiously, to do haven 'sacrifice' without mantras and to protect the Brahmins, these are the primary duties of a Sudra

These verses are followed by people of society and as a result seed of caste division is sown. The people of Kanthapura firmly believed in the theory of caste differentiation. The villagers lived in separate places according to their caste. "Our village had a Pariah quarter too, a Potters' quarter, a Weavers' quarter, and a Sudra quarter". Brahmin is considered superior to other caste and Sudras are considered the lower caste and nobody is allowed to even sit near them. Muslims also remain outcaste and therefore untouchables. Bade Khan being a Muslim is not allowed to sit in the village. And people like Ranga Gowda threatened everyone who mingles with the lower caste. "If he does not stop mixing with the pariahs, this very hand-do you hear? this very hand will give him two slaps on his cheeks . . . The Swami has said that if this pariah business is not stopped immediately the village will be excommunicated. This idea of caste is engraved in peoples mind and thus this idea has become a myth which cannot be broken easily. This myth has coiled our society in such a way that who so ever tries to break it the whole society stands against him. This problem is raised by many authors in their work. Gandhi tried to remove this myth from its roots. He called the people of lower caste "Harijan" or "Disciple of god" and gave them equal respect, honour and power. But from centuries, there are many myths developed around each caste of. For example, The myth developed around Brahmin's is that they live a simple and religious life abiding by the norms of the society and his caste. The fact is that the Brahmins of 
Kanthapura are after money Bhatta became richer and richer. He could lend out more money. He was a land owner he was living a pious life as stated in our videos rather he ais after money and feasts.

The myth of caste differentiation is broken by Morthy in the novel. Moorthy visits the quarters of untouchables and mingle with them. But in the starting, we see that myth is so strong that he hesitated to mingle with them But Rachanna's wife quickly sweeps a corner and spreads for him a wattle mat, but Moorthy, confused, blurts out, 'No, no, no, no'... he smelthe ls the stench of hiding and the stench of pickled pigs, and the roof seems to shake, and all the gods and all the manes of heaven seem to cry out against him, and his hands steal mechanically to the holy thread, the holding it, he feels he would like to say, 'Hari-Om, HariOm'. This shows the concept of caste is so rooted in the psyche of people that even if they want they cannot escape it. These lines project the dilemma of being a Brahmin on one side and a Gandhian on another side. But towards the end of the novel we see that Moorthy and many other people of gradually overcome the idea of castesim and the whole village was fighting against this ideology. The evil of caste differentiation gets feeble and people of other caste plunge into the movement shoulder to shoulder.

Women as weaker section of society as a myth

"Women have been given a lot of power by nature but very little by law" - Samuel Johnson.In our society women are considered the weaker section of society. They are less educated, they are not acknowledged in political and public sphere, they are made to be dependent on men. First on their father than their husband and in the end on their son. Their space is restricted to the domestic sphere of life only and remains under purdah "veil". Raja Rao is a highly learned, sensitive and imaginative author. He represents her female character as a Shakti or the women power. He has a very high idea of the position of women in society. 
Kanthapura holds a very negative idea about women and there are many restrictions as to what women can do and what not. Raja Rao presents the legend of Kenchamma, the Goddess of the hill, and raises it to the level of a myth. Goddess Kenchamma slays the demon who comes to ask for the young men of the village as food and the young women as wives. Her name is repeated throughout the novel. At all times of trouble, the village turn to Kenchamma to come to their rescue, as she once did in the remote past. But in their house, the same people never respect their women and if a woman tries to go against the boundaries set by the society they do not tolerate it. For instance, when young Ratna a young widow oppose to remain isolated from society like other women she is looked down upon by the members of the community. In the same way Moorthy mother is threatened by the society that her son will be thrown out of society because he is mingle with people of lower caste. Being an illiterate woman, she gets a big shock because for her all the unwritten laws of the society are the ultimate truth and, in the end, we see that she dies because of this pressure. This myth of women being the suppressed class gets broken towards the end of the novel. The women of Kanthapura play a dynamic role in the national freedom. They were no longer passive followers of men. They fought against Britisher's shoulder to shoulder with men. Women quality of leadership is shown in the end when rangamma takes the lead to organize freedom movement in the village when Moorthy was sent to prison. She motivates all the women by telling stories of Rani Laxmi Bai. She inspires them to fight against the British like the city women. She says, "We are but unworthy of all these people . . . Kamladevi and Sarojini Naidu and Annie Beasant all the heroic daughters who fight for the Mother- and we, we think of nothing but the blow pipe and the broom stick, and the milking of the many cows. We, too, should organize a Volunteer . In the leadership of Rangamma they form Sevika Sangh 'organisation for serving'. This unit organizes passive resistance against the 
wickedness of foreign rule. The myth that women should be passive and should follow their husband whether it is in politics, home or market is broken in the end.

A great leap for shattering this myth is achieved by the author is by selecting narrator of the novel as an old female. This is one of the rare novels where history is looked from the perspective of women. Brahmin widow, Achakkashe narrates the story of Kanthapura. History is often considered male dominance. The word when divided is his+story. It talks about men story their achievements, fights, lifestyle and place in society Written by men and about men only. The greatest history book of our time Mahabharat written by Vyasa who is again a male and in Mahabharat we see how the whole story is constructed around the war and on Draupadi who was robbed. The myth that women are weak gets broken. The reality is that they are mentally stronger than men. While facing the lathis 'sticks' of British, they do not bend under pressure as easily as men do. Sitara makes an apt comment in The Emergence of the Woman: A Reading of Raja Rao's Kanthapura: Kanthapura is a path-breaking work in many ways. It is Raja Rao's sensitive and realistic portrayal of the emergence of the modern Indian woman. From the polar images of the all-powerful Goddess Kenchamma and the Pariah Rachana's wife who would spin only if her husband tells her to, emerge the new women who defy conventions and lead the war of independence.

The novel is a fresh breath of change with a depiction of women who shed the old age bars of customs and orthodoxy by actively taking part in the freedom movement. The enthusiasm of both men and women and their equal participation in the freedom struggle reflects that women of Kanthapura have taken a great leap from the past to the present.

The Gandhian Myth

Jawaharlal Nehru once said "Gandhi is like a powerful current of fresh air like a beam of light that pierced the darkness removed the scales from our eyes, like a whirlwind 
that upset many things, but most of all the working of people's mind" The powerful current of fresh air aroused national awakening in Indians and gave them strength to fight against thirsty Britisher . Gandhi has left a permanent mark on India. Literature thus could not remain untouched by Gandhi.

Many writers have written about Gandhi and his ideologies. Mulk Raj Anand also wrote about Gandhi ideas in Untouchable but he did not idealise Gandhi in his novel. But on the other hand, Raja Rao almost substitutes the mythical character with the contemporary ones in Kanthapura. Raja Rao in his novel presents Gandhi as a mythical character . The blending of myth and reality is almost perfect and meticulous in execution. Gandhi's character in Kanthapura has been idealized like that of Rama in the Ramayana. Like Rama, Gandhi is described as the reincarnation of the almighty. His psychological presence in the novel lends a mythical aura around his saintly figure. The exploitation of Indians by Britishers is explained to villagers like Ravan the British have come to kidnap our sita that is our freedom. Gandhi visit to England to attend the round table conference in 1913 is described in terms of Indian mythical tradition. Same as Ram visit to Lanka to save Sita from Ravan. Gandhi's idea of Swaraj has been compared to the three eyes of shiva: Selfpurification, Hindu-Muslim unity, khaddar.

The birth of Gandhi is described as mythical by Jayaramchara. Who singes praise of God and narrates the legend of related to God called the Harikatha. He narrates the story that sage Valmiki approaches Lord Bramha and tells that the beautiful land of India is enslaved by foreigners, people are dying of the atrocities. He requests Lord Bramha to take some action and Bramha blesses him saying that Siva himself will take birth in a Gujarati family and so is Gandhi born. Jayaramchar says while reciting Harikatha 'Legend of God', “And lo! When the sage was still partaking of the pleasures Brahma offered him in hospitality, there was born in a family in Gujarat a son such as a world has never be held. As soon as he came forth, the 
four wide walls began to shine like the kingdom of the sun and hardly was he in the cradle then he began to lisp the language of wisdom". Therefore the people of Kanthapura take Gandhi as a reincarnation of Shiv and they started worshiping him like a god and followed his ideologies as a religious text. This strategy is used by the author to make innocent people understand the idea and importance of freedom. He finished his vow, the gods will come down and dissolve his vow, the Britishers will leave India, and we shall be free, and we shall pay less tax, and there will be no policemen". This vow is the vow taken by Gandhi to make India a free nation during Dandhi march. People of Kanthapura compare it to Krishna's victory over the serpent Kaliya.

In the novel, we see how Gandhi as a person of flesh and blood is not present throughout the novel like "Godot" in Samuel Beckett's Waiting for Godot. The mythical design makes his novel more effective and impactful to the readers.

Sthala-Purana 'Localised Myth’ as a Religious Myth

There is no village in India, however mean, that has not a rich sthala-Purana, or legendary history, of its own. Some god or godlike hero has passed by the village-Rama might have rested under this pipal-tree, Sita might have dried her clothes, after her bath, on this yellow stone, or the Mahatma himself, on one of his many pilgrimages through the country, might have slept in this hut, the low one, by the village gate.

These lines explain the idea of Sathala Purana that is a "localised myth". Sathala purana is a part of every village or town of India. Every place is associated with some story of God and goddesses. This Sathala-Purana give us the myth of religion in Kanthapura. The religious activities and religious myths are very important aspects of the novel. There is a number of puranic or mythical devices in Kanthapura. A very important myth of village is the 
figure of Kenchamma the deity of the village. There is a folk song which evokes in us the images and attitudes as to what Kenchamma means to the people of Kanthapura,

\author{
Kenchamma, Kenchamma, \\ Goddess benign and bounteous, \\ Mother of earth, the blood of life, \\ Harvest queen, rain crowned, \\ Kenchamma, Kenchamma, \\ Goddess benign and Bounteous
}

People in the village believe that Kenchamma that she will never disappoint them and is always there with them to save them from demos. The myth of Kenchamma as told is, "Kenchamma came from the Heavens-it was the sage Tripura who had made penances to bring her down and she waged such a battle and she fought so many a night that the blood soaked and soaked into the earth, ... Kenchamma hill is all red" This is the Sathal-Purana of Kanthapura. The temple of Kenchamma is a significant place in the novel. It is here that the activities of freedom movement, the celebration of festivals take place. Since Gandhi is described as a god, so everything related to him takes place in and around the temple. The temple is the symbolic representation of present also. It provides the venue for Harikatha "mythological legend" and political activities also take place here. There is an intermingling of religious and political myth. In the course of the novel, we see that people get the strength to fight against the Britishers from this temple only.

Another localized myth is of the river Himavathy The river is considered to be the daughter of Kenchemma. Himavathy is to Kanthapurians what Ganga is to all Indians. A holy dip in the river purges them of all evils. Moorthy is asked to take bath in the river to get purified again as he had visited Pariah quarters. Mukherjee says: "As soon as the local legend has been narrated and established, its function becomes the same as that of a more well- 
known myth" As Mukherjee rightly points out the myth of goddess Kenchamma and river Himvathy are the reality of the villagers. For them, it is not a story that will never lose its essence after some time. They have a firm belief in these myths Rajo Rao has depicted the religious mindset of the people and thus he has mythologized the reality. The reality of the freedom struggle is also influenced by the mythical thinking of the people. The idea of the reality of Kanthapurians is influenced by myth.

\section{Conclusion}

Myths and symbols occur in the novel as a creative mode of conveying "a meaningful world-view of human reality in terms of shared experience. Thus, there is a perceptible mythical pattern in Kanthapura. The author employs myth to extend understanding of situation or give symbolic meaning to the text. As a great artist, he often assimilates the myth into the narration. In the novel author has not only created some myth rather some myths are also broken in the course of novel. Myths that are dehumanizing human. Separating one human from other and leading our society towards dark side. But in the novel author has taken a middle position neither he is criticising myths completely neither he is favouring them. Through this is myths only author is able to make people understand the dangeroure India was facing dangerous of. Kanthapura no doubt, is significantly presenting the collision of two rival forces as is formed in myth. 


\section{Bibliography}

Piciucco Pier Paolo, The Fiction of Raja Rao: Critical Studies Atlantic Publishers and

Distributors Pvt Ltd (2001)

Rao, Raja. Kanthapura. Orient Paperbacks. New Delhi. 2008.

Mukherjee, Meenakshi. Myth as Technique in Twice Born Fiction. Heinemann, New Delhi. 1974. Iyenger, K. R. Srinivasa. Indian Writings in English. Sterling publishers. New Delhi. 1993. Print.

https://www.academia.edu/9220048/Mythical_Technique_in_the_Novels_of_Raja_Rao Mythical Technique in the Novels of Raja Rao http://solankipintu.blogspot.in/2015/10/kanthapura-as-sthala-purana.html - Kanthapura as a sthala-purana 